\title{
Study of the mutual connections among Information- communication Technologies, Organisational Learning and Business Performance
}

\author{
Miha Škerlavaj, Vlado Dimovski**
}

This paper presents the results of a study (involving 220 larger Slovenian companies) which aimed to examine the influence of information and communication technologies (ICT) and organisational learning (OL) on both financial (FP) and non-financial performance (NFP). In this manner a structural equation model was conceptualised based on prior theoretical and empirical foundations. According to responses from Slovenian CEOs, the statistically significant and positive influence of ICT on FP and NFP were established. No support for the 'ICT productivity paradox' can be provided by our research. Future longitudinal research needs to establish whether the ICT productivity paradox is the reverse image of organisational learning.

Der Aufsatz präsentiert die Ergebnisse einer Studie (von 220 größeren slowenischen Firmen), die darauf abzielt, den Einfluss von Informations- und Kommunikationstechnologien und organisatorischem Lernen auf den finanziellen und auch nichtfinanziellen Erfolg zu untersuchen. Somit wurde ein strukturelles Modell konzeptualisisiert, das auf früheren theoretischen und empirischen Annahmen fundiert. Anhand von Antworten slowenischer Führungskräfte wurden statistisch wichtige und positive Einflüsse der Technologien auf die betreffenden Kriterien erfaßt. Die Technologien haben jedoch keinen statistisch wichtigen Eindruck auf den nichtfinanziellen Erfolg. Zukünftige Forschung ist nötig, um darzustellen, ob das ICT Produktivitätsparadoxon das umgekehrte Abbild vom organisatorischem Lernen ist.

Key words: Organisational learning / information-communication technologies / productivity paradox / organisational performance / Slovenia.

* Manuscript received: 13.05.05, accepted: 19.12 .05 (1 revision)

** Miha Škerlavaj, University of Ljubljana, Faculty of Economics. Main research areas: General Management, Organisational Learning, and Business Informatics. Corresponding address: miha.skerlavaj@ef.uni-lj.si

Vlado Dimovski, University of Ljubljana, Faculty of Economics. Main research areas: Strategic Management, General Management, Organisational Learning, and Business Research Methods. 


\section{Introduction}

We can consider 1993 as the beginning of the era called the new or e-economy. This was the year the Internet moved out from its military-research cocoon into general commercial use. This step was reflected in a tremendous expansion in information-communication technologies for business and rapid growth in investments. However, earlier authors (Roach 1987) argued that ICT still did not pay off in terms of the required productivity growth. Solow (1987) even said that we were seeing computers everywhere except in the productivity statistics. This phenomenon was called the 'productivity paradox' and it asserts that IT investments do not result in productivity gains (Navarette/Pick 2002). Even today Carr (2003) believes that 'IT may not help a company gain a strategic advantage, but it could easily put a company at a cost disadvantage'. At the same time, he adds that you can only gain an edge over your rivals by doing something they cannot.

As de Geus (1989:1) suggested, that 'while all companies learn, the crucial element is to be able to learn fast enough to sustain a competitive advantage' and that 'this is becoming increasingly important in today's fast-changing competitive world'. Indeed, most modern empirical studies (Dewan/Kraemer 1998; Navarette/Pick 2002; Dimovski/Škerlavaj 2003) tend to reject the productivity paradox thesis, which can lead us to the important assumption that it may be regarded as a reflection of a learning curve. In other words, organisational learning can be seen as a way out of the dilemma called the productivity paradox. In the last few decades the field of organisational learning has attracted a lot of interest from academics as well as practitioners. A key question in this context is what the connection between ICT and organisational learning is, and what kind of impact they both have on business performance. Bearing this in mind, a structural model was developed and tested on a sample of 220 larger Slovenian companies.

The paper has four parts. In the first section, we examine relevant theories in the field of organisational learning, information-communication technologies and modern approaches to evaluating organisational performance in order to develop a set of constructs and an empirical basis for the relationships among them. In the second part, the model's operationalization through the development of a measurement submodel is presented. In the third section, the model is tested using a structural linear modelling technique. We conclude with a discussion of the managerial implications of the results and offer some guidelines for future research in the area while acknowledging the limitations at hand. 


\section{Structural submodel's conceptualisation}

In order to develop a sound model a structural framework must first be developed. This phase consists of two steps: a presentation of the constructs and an examination of possible relationships among them.

\subsection{Presentation of the constructs (latent variables)}

ICTs have become a major facilitator of business activities in the modern world (Tapscott/Caston 1993; Gill 1996) and are also the main catalyst of fundamental changes in the structure, operation and management of organisations (Dertouzos 1997). One of the taxonomies most often used for ICT for business is that which differentiates among software, hardware and telecommunications (Turban et al. 2001; Beynon-Davies 2002).

The main components of hardware not only involve computers but also several attached technologies that take care of data (or information) flows into and from computers. Turban et al. (2001) define hardware as physical equipment applied to the following activities of a computer system: input, process, output and storage of data. The main components of hardware are the central processing unit (CPU), memory (primary and secondary storage), input technologies, technologies to display results and communication technologies. What needs to be noted is that communication technologies play such a crucial role that they are very often regarded as an entity per se and discussed in relation to networks. The central processing unit performs actual computations within the computer.

The user value of most hardware equals zero if it is not combined with software. Beynon-Davies (2002) divides application and system software and sees the latter as a link between hardware and application software. At this point, we encounter enterprise-resource-planning (ERP) systems which are an important development for modern businesses because they integrate data and information from transaction-processing systems, decision-support systems and executiveinformation systems. At present, their essence is business-level data and information integration. However, we can expect that this integration will exceed the individual firm's boundaries and be used for inter-firm collaboration (i.e. connection to firms' main suppliers and customers). Not unlike hardware, the power of computer software doubles approximately every eight years (Turban et al. 2001). The reason for this can probably be attributed to the market structure of software providers that can best be described as a monopoly or oligopoly in certain segments. It will be interesting to monitor future advances in this area with regard to open-source software. In segments where there are open-source alternatives, the quality of commercial products is rising and their prices are declining.

The third component of information-communication technologies, which has allowed for the expansion of various networks, are communication technologies. 
The Internet is clearly the most important network. It has had an impact on the birth of the so-called 'new economy' mainly due to its inter-connectivity of various systems.

The concept of organisational learning is often confused with the concepts of the learning organisation, knowledge management and/or organisational knowledge. Easterby-Smith and Lyles (2003) provide a comprehensive and systematic mapping of the area and differentiate between four terms using two continuums: theory vs. practice and content vs. process (Figure 1). The distinction between organisational learning and the learning organisation is explained to the extent that organisational learning refers to the study of learning processes of, within and between organisations largely from an academic point of view. On the other hand, the learning organisation is considered as an entity - an ideal form of organisation, which has the capacity to learn effectively and hence to prosper (Tsang 1997). Besides the structure vs. process differentiation, the difference between organisational learning and the learning organisation can also be seen from another perspective. While organisational learning tends to be positive and descriptive, the idea of the learning organisation tends to be normative and prescriptive in its nature.

Figure 1. Mapping the area of organisational learning, learning organisation, knowledge management and organisational knowledge (Adapted from EasterbySmith and Lyles, 2003).

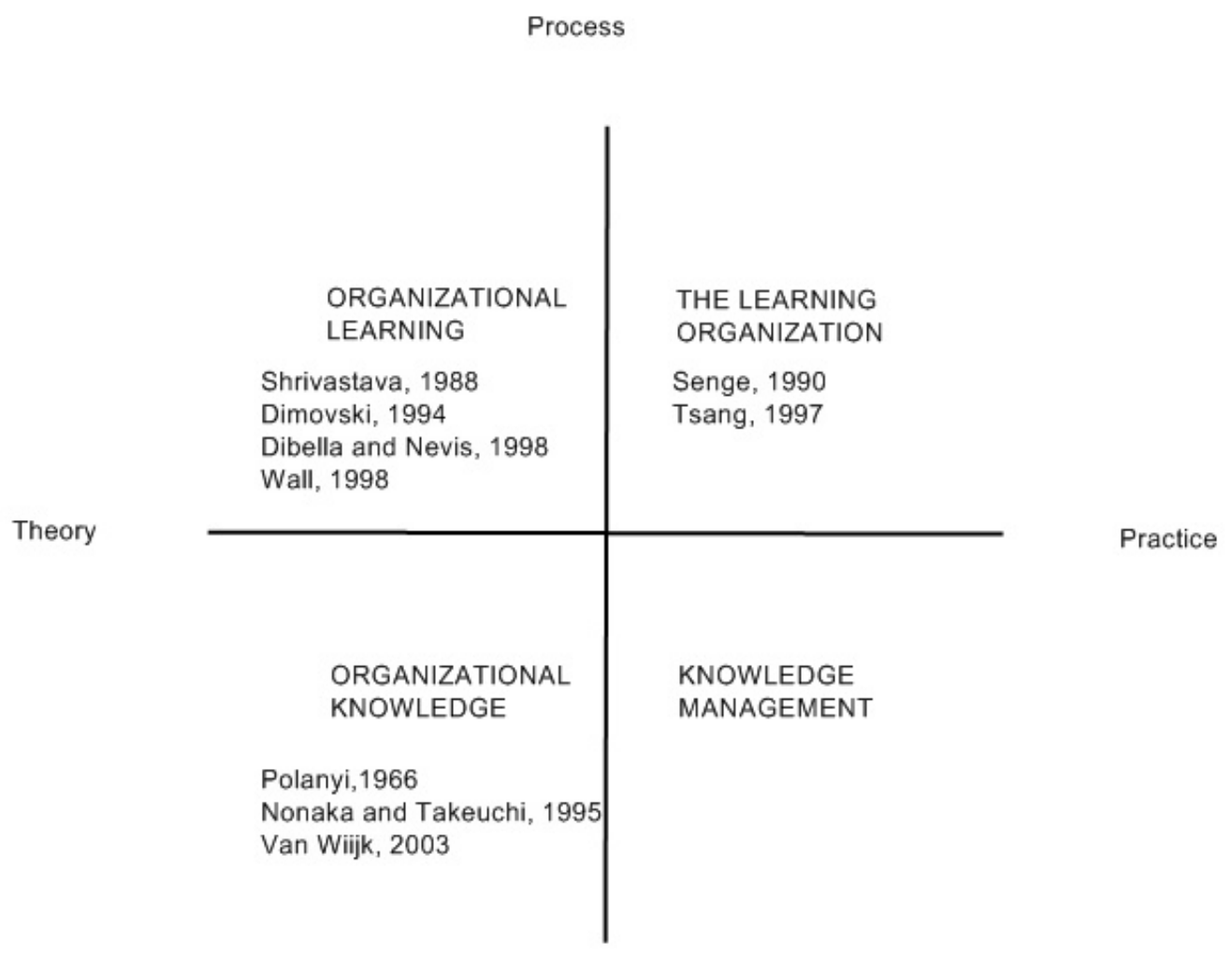


An analogous distinction can be drawn between the terms organisational knowledge and knowledge management. Many authors (Polanyi 1966; Nonaka/Takeuchi 1995; Van Wiijk 2003) elaborate on the tacitness and explicitness of organisational knowledge, explain various forms of its conversion through the well-known SECI model, and in recent times study knowledge networks as a major conduit for knowledge transfer. Those writing about organisational knowledge often adopt a philosophical slant in trying to understand and conceptualise the nature of knowledge that is contained within organisations (Easterby-Smith/Lyles 2003). On the other hand, the knowledge management literature frequently adopts a technical approach directed to disseminating and leveraging knowledge in order to enhance organisational performance. Information-communication technologies lie at the centre of such discussions. The first dichotomy by which we can understand the field is one of theory vs. practice. The second dichotomy is one that sets process apart from content. While knowledge is a content, which an organisation possesses (or not), learning is a process, which leads towards acquiring knowledge. We focus on organisational learning and deal with the challenge of how to operationalise such an elusive concept.

The organisational learning construct (OL) could well be the most ambiguous part of the model. While some leading researchers (Shrivastava 1983; Dimovski 1994) found that the majority of research in the area has been fragmentised and incomplete, while research in the field of organisational learning has resulted in many definitions and models (e.g. DiBella/Nevis, 1998; Nonaka/Takeuchi 1996; Wall 1998), recent research (Easterby-Smith/Lyles 2003) has provided a better understanding of the domain. Senge (1994: 11) defined organisational learning as 'a continuous testing of experience and its transformation into knowledge available to the whole organization and relevant to their mission', while Huber (1991) saw it as a combination of four processes: information acquisition, information distribution, information interpretation and organisational memory. Argyris and Schön (1996) were less restrictive in their definition by declaring that organisational learning emerges when organisations acquire information (knowledge, understanding, know-how, techniques and procedures) of any kind and by any means. Apart from that, Jones (2003) emphasises the importance of organisational learning for organisational performance, defining organizational learning as a process through which managers try to increase the capabilities of members of the organization in order to better understand and manage the organization and its environment to accept decisions that increase organizational performance on a continuous basis. Dimovski (1994) provided an overview of previous research and identified four various perspectives on OL. His model managed to merge the informational, interpretational, strategic and behavioural approaches to OL and defined it as a process of information acquisition, information interpretation and resulting behavioural and cognitive changes which should, in turn, have an impact on organisational performance. 
The purpose of information acquisition is to reduce uncertainty (Daft/Lengel 1986), which was defined as a lack of information by Shannon and Weaver (1973). The meaning, uncertainty and quantity of information should be negatively correlated (Daft/Lengel 1986). Here, we would like to add that there is an optimal quantity of information. Namely, an information overflow probably limits an organisation's capacity to interpret the information at hand.

Information acquisition is determined by two variables: data sources and the intrusiveness of the organisation (Daft/Weick 1984). Data sources can be internal or external (Daft/Lengel 1986), with external sources representing managers' direct contacts with information sources outside the firm's boundaries, and internal sources including employee data collection conveyed later (in the form of information) to managers using internal data channels. Recently, in this context a very important role has been played by informationcommunication technologies (such as intranet, enterprise-resource-planning systems, and e-mail). The intrusiveness of an organisation is defined as the extent to which an organisation is capable of actively penetrating its environment by browsing and searching for the desired data and information. With this criterion organisations can be clustered into active or passive groups. On one hand, active organisations allocate resources to search for information (e.g. they have employees to deal with research activities, hire external experts, and actively use the Internet in order to obtain information for decision support, use extranet or ERP II systems as a form of connecting to external partners suppliers and major customers). On the other hand, passive organisations accept all information offered by their environments at a certain moment in time (King 1980). We would like to think of the distinction between active and passive organisations as involving continuum (rather than a dichotomy) and will treat it as such in our further research.

The purpose of interpreting information is to reduce ambiguity related to the information. Ambiguity can be defined as the existence of multiple, contradictory, explanations of the situation at hand (Daft/Lengel 1986). Two variables describe information interpretation: richness of media (Daft/Weick 1984) and 'top-down' processing (Martello 1993). Richness of media relates to the capabilities of various media forms to process information. The richest medium is personal contact, followed by telephone conversations, written memorandums and letters, special reports and a formal chain of command as the 'poorest' medium (Daft/Lengel 1986). Modern media, for instance, involve videoconferences as a 'richer' media and electronic mail or intranet as 'poorer' forms of media for interpreting information. The 'top-down' concept of processing assumes that individuals' past experiences, and the context in which they were obtained, reaffirm the valid analytical framework to understand future developments. The purpose of 'top-down' processing is to improve how employees at lower levels of the organisational structure understand information 
and is dependant on the level of details (Martello 1993) and frequency of information cycles or information dissemination using various communication channels (Daft/Weick 1984).

Organisational learning is reflected in 'accompanying changes' (Garvin 1993). If no behavioural or cognitive changes occur, organisational learning has in fact not occurred and the only thing that remains is unused potential for improvements (Fiol/Lyles 1985; Garvin 1993). When discussing cognitive changes two levels of learning can be observed. Lower-level learning reflects changes within the organisational structure, which are short-term and only partially influence the organisation. Higher-level learning reflects changes in general rules and norms (Fiol/Lyles 1985). Argyris and Schön (1978) classified learning similarly: single-loop and double-loop learning, Dodgson (1991) discussed tactical and strategic learning, while Senge (1990) used the terms adaptive and generative learning. By all means, at a lower level the learning organisation acts passively and only adapts to its environment, while higherlevel learning involves an active influence on the business environment.

How can we evaluate organisational performance? Clearly, it cannot be done without taking organisational goals into consideration. The modern business environment demands a multi-goal orientation. Profit theory (Cyert/March 1963) is no longer a valid measure of organisational performance, nor are other approaches that only take the interests of shareholders (owners) of a company into consideration. Today's business environment is characterised by the increased importance and strength of customers, employees and society in general. It has become quite obvious that all stakeholders need to be taken into account in a modern company performance assessment. This is the main idea of Freemans' stakeholder theory $(1984 ; 1994)$. Even the behavioural theory of a company (Cyert/March 1963) acknowledges that company is a coalition of individuals or groups of individuals such as management, employees, customers, owners, government etc. Besides financial performance, non-financial performance must also be assessed in order to evaluate the overall organisational performance of the modern company. According to Rejc (2002), there are two main reasons for this requirement. First, in business there are several interest groups involved and they all have their own particular goals and expectations related to the company. They will only remain in the coalition if their goals will be satisfied in a sufficient manner. Second, strategic business areas are not necessarily financial in nature. Several approaches to non-financial indicators selection exist, the most established of which is the Balanced Scorecard - BSC (Kaplan and Norton 1992; 1993; 1996; 1996a).

\subsection{Relationships among the latent variables}

There is a vast body of research dealing with the influence of ICT (investments, usage etc.) on (mainly financial) organisational performance. It can be divided 
into four streams of research based on observed units: business, industry, national and international levels. The results are mixed. Some recent studies in our context (Dimovski/ Škerlavaj 2003) that analysed the influence of hardware, software, telecommunications and knowledge investments on value added per industry for Slovenia in 1996-2000 demonstrated the statistically significant and positive influence of hardware and telecommunication investments on value added. These two independent variables summed up to nearly $75 \%$ of total ICT investments in Slovenia in the given time period, so the following hypotheses can be posed:

$H_{1}$ : Information and communication technologies (ICT) have a positive impact on financial performance (FP).

$\mathrm{H}_{2}$ : Information and communication technologies (ICT) have a positive impact on non-financial performance (NFP).

Next, the impact of organisational learning on financial and non-financial performance needs to be examined. Dimovski (1994) confirmed the positive impact on both aspects of performance measures, using a one-industry research design and a stratified sample of 200 credit unions in Ohio based on the asset size criterion. This study investigated the determinants, process and outcomes of organisational learning, as well as the relationship between organisational learning and performance. Sloan et al. (2002), Lam (1998) and Figueireido (2003) also reached similar conclusions. Simonin (1997) found strong effects of learning on financial and non-financial performance in the context of strategic alliances. Specifically, he tested for the influence of collaborative know-how on tangible as well as intangible collaborative benefits. Tangible benefits are strategic and financial: generating additional profits, improving market share, and sustaining competitive advantage. Intangible benefits are learning or knowledge-based: learning specific skills and competencies (Kogut 1988), learning about inter-firm co-operation (Lyles 1988), and learning how to behave co-operatively (Lane/Beamish 1990).

We have to be aware of the fact that various aspects of organisational learning contribute to performance. Pisano et al. (2001) examine learning curves in the health-care setting and determine that organisations achieve performance improvements (improve work processes - reduce procedure times, hence increase efficiency) based on cumulative experience at different rates. Cohen and Levinthal (1990) argued that a firm's ability to recognise the value of new, external information, assimilate it, and apply it to commercial ends (called absorptive capacity) is critical to its innovative capabilities. Darr et al. (1995) examined the acquisition, depreciation and transfer of knowledge acquired through learning by doing in a service organisation and found evidence of learning: as organisations gain experience in production the unit cost of production declines significantly. On this basis, the following hypotheses can be put forward: 
$H_{3}$ : Better organisational learning $(\mathrm{OL})$ leads to better financial performance (FP).

$H_{4}$ : Better organisational learning (OL) leads to better non-financial performance (NFP).

Robey et al. (2000) provide an overview of research related to the relationship between our two exogenous latent variables ICT and OL. They witness 2 main streams of research (one related to ICT as a facilitator of OL and the other aimed at OL concepts to help develop and implement ICT in companies). Based on their research the following hypothesis can be established:

$H_{5}$ : The correlation between ICT and OL is positive.

Empirical literature is quite scarce regarding endogenous constructs. Interestingly, based on research among 12 UK-based companies Chakravarthy (1986) found no statistically significant relationship between FP and NFP and so our last hypothesis for the structural submodel is:

$H_{6}$ : There is no correlation between FP and NFP.

Once the structural submodel has been developed, our next task is to operationalise the latent variables in order to develop a measurement submodel to test the hypotheses posed in the previous phase.

\section{Measurement submodel's development}

For the purposes of the model's operationalization we developed a self-reporting questionnaire with 11 measurement variables and 56 items on a five-scale basis through item aggregation. In Table 1 we present the constructs, their indicators, number of items aggregated in each, and the authors of the underlying empirical research/theories used to develop the measurement instrument.

The ICT construct had 3 measurement variables: hardware (HW), software (SW) and telecommunication equipment (TCM) with 3,6 and 5 five-scale items aggregated. Our research interest was directed to the frequency of enterpriseresource-planning (ERP) systems usage, the frequency of groupware, intranet, database management systems, e-forums usage, share of employees with and the speed of their Internet access, the share of employees with a PC or terminal and mobile computers or palms at their workplace etc.

Three indicators were used to measure the OL construct: information acquisition (INFOACQ), information interpretation (INFOINT), and behavioural and cognitive changes (BCC). When reporting on INFOACQ, respondents were asked about the importance of different sources of information (such as employees, previous decisions, external experts, clipping, competition, external data sources etc.). The importance of several ways to interpret information (personal contacts, teams, phone contacts, reports, memos etc.) was used to 
measure INFOINT. The measurement variable BCC was aggregated from 14 items asking about changes in the last three years in certain organisations in several areas (such as adaptability to pressures from the external environment, quality of products or services, general atmosphere in the company, efficiency of team meetings, speed of business etc.)

Table 1. Specification of constructs - latent variables, their indicators, number of measurement items and their sources

\begin{tabular}{|c|c|c|}
\hline $\begin{array}{l}\text { Latent variables } \\
\text { (constructs) }\end{array}$ & $\begin{array}{l}\text { Measurement variables (indicators) and } \\
\text { number of items aggregated into each }\end{array}$ & Source \\
\hline $\begin{array}{l}\text { Information and } \\
\text { communication } \\
\text { technologies } \\
\text { (ICT) }\end{array}$ & $\begin{array}{l}\text { - Hardware }(\mathrm{HW})-3 \text { items } \\
\text { - Software }(\mathrm{SW})-6 \\
\text { - Telecommunication equipment }(\mathrm{TKM})-5\end{array}$ & $\begin{array}{l}\text { - Turban et al. } 2001 . \\
\text { - Beynon-Davies } 2002 . \\
\text { - Andersen /Segars, } \\
2001 .\end{array}$ \\
\hline $\begin{array}{l}\text { Organisational } \\
\text { learning }(\mathrm{OL})\end{array}$ & $\begin{array}{l}\text { - Information acquisition (INFOACQ) - } 12 \\
\text { - Information interpretation (INTINF) - } 11 \\
\text { - Behavioural and cognitive changes (BCC) - } \\
14\end{array}$ & - Dimovski 1994. \\
\hline $\begin{array}{l}\text { Financial } \\
\text { organisational } \\
\text { performance (FP) } \\
\text { - perspective of } \\
\text { owners }\end{array}$ & $\begin{array}{l}\text { - Return on assets (ROA) - } 1 \\
\text { - Value added per employee (VAEMP) - } 1\end{array}$ & \multirow{2}{*}{$\begin{array}{l}\text { - Rejc } 2002 . \\
\text { - Freeman 1984; 1994: } \\
\text { Stakeholder theory. } \\
\text { - Kaplan/ Norton 1992; } \\
\text { 1993; 1996; 1996a: } \\
\text { Balanced scorecard. } \\
\text { - Chakravarthy 1986. }\end{array}$} \\
\hline $\begin{array}{l}\text { Non-financial } \\
\text { organisational } \\
\text { performance } \\
\text { (NFP) - } \\
\text { perspective of } \\
\text { other stakeholders }\end{array}$ & $\begin{array}{l}\text { - Stability of relationships with suppliers } \\
\text { (SUPPLY) - } 1 \\
\text { - Net fluctuation of employees (EMPLOY)- } \\
1 \\
\text { - Customer complaints (BUYER) - } 1\end{array}$ & \\
\hline
\end{tabular}

The latent variable FP was measured with two one-item measurement variables: return on assets (ROA) and value added per employee (VAEMP) in the last three years relative to the industry average using a bipolar scale. These results will reflect the business performance from the owners' point of view. The same approach is used for non-financial organisational performance (NFP) to capture the perspectives of other stakeholders in the firm as a coalition of interests. The three one-item variables used here are the stability of relationships with suppliers (SUPPLY), net fluctuation of employees (EMPLOY) and customer complaints (BUYER).

\section{Methodology and results}

The methodology applied to test our model was structural equation modelling (SEM). This involves a combination of confirmatory factor analysis (CFA) and econometric modelling, which aims to analyse hypothesised relationships among the latent constructs, measured with observed indicators (measurement 
variables). The complete SEM model has two parts - structural and measurement sub-models. A key advantage that SEM has over multiple regression is that it allows for the simultaneous testing of multiple endogenous (dependent) variables. On the other hand, SEM demands relatively large samples. Diamantopoulos and Siguaw (2000) propose at least 200 units as a rule of thumb, even though the required sample size depends largely upon the number of parameters to be estimated.

\subsection{Data gathering and sample}

Based on the model's conceptualisation, a measurement instrument (questionnaire) was developed and sent in June 2003 to the CEOs or board members of all Slovenian companies with more than one hundred employees, which accounted for 867 companies. In the first three weeks 234 completed questionnaires were returned, 14 out of which were excluded from further analysis due to missing values. The response rate was $25.4 \%$, which can be considered successful in the Slovenian context (using our primary data collection technique and no call backs). It is an indication that, beside academia, managers are also interested in the question of whether, and in which circumstances, investments in ICT pay off.

We aimed at an audience of top managers bearing in mind the idea of having a strategic and to some degree even an interdisciplinary perspective on the company in question, although there is some discrepancy between the desired and actual structure of respondents. Figure 2 depicts the structure of respondents by their function. The structure of our sample by company size is a good representation of the population of large Slovenian companies. Based on the criterion of the average number of employees, in $200251.4 \%$ of the companies had between 100 and 249 employees, followed by $24.6 \%$ with 250 to 499 employees, $11.8 \%$ had $500-999$, while $12.2 \%$ of the companies had 1,000 or more employees.

Table 2 demonstrates the industry structure of the companies in question. Our respondents reported in almost half of all cases that their main industry was manufacturing, followed by $10.5 \%$ of companies in the construction business and $9.1 \%$ in trade and the repair of motor vehicles. Four out of fifteen industries only have one representative each, while there was no company stating fishery and education as its main industry. This is logical since we excluded non-profit and small businesses from our analysis.

Table 2. Structure of respondents - by industry

\begin{tabular}{|l|l|c|c|}
\hline \multicolumn{1}{|c|}{ Industry (SIC) } & Frequency & Percent \\
\hline A & Agriculture, Hunting and Forestry & 8 & 3.6 \\
\hline B & Fishing & 0 & 0 \\
\hline
\end{tabular}




\begin{tabular}{|l|l|c|c|}
\hline C & Mining and Quarrying & 1 & .5 \\
\hline D & Manufacturing & 107 & 48.6 \\
\hline E & Electricity, Gas and Water supply & 14 & 6.4 \\
\hline F & Construction & 23 & 10.5 \\
\hline G & $\begin{array}{l}\text { Wholesale \& Retail, Repair of motor vehicles, } \\
\text { Personal \& Household goods }\end{array}$ & 20 & 9.1 \\
\hline H & Hotels and Restaurants & 6 & 2.7 \\
\hline I & Transport, Storage and Communication & 12 & 5.5 \\
\hline J & Financial intermediation & 13 & 5.9 \\
\hline K & Real Estate, renting and business activities & 1 & .5 \\
\hline L & Public Administration and Defence, Compulsory \\
& Social Security & 1 & .5 \\
\hline M & Education & 0 & 0 \\
\hline N & Health and Social Work & 1 & .5 \\
\hline O & $\begin{array}{l}\text { Other Community, Social and Personal Service } \\
\text { Activities }\end{array}$ & 13 & 5.9 \\
\hline Total & \multicolumn{2}{|c|}{} & \\
\hline
\end{tabular}

Figure 2. Structure of respondents by their function within their company

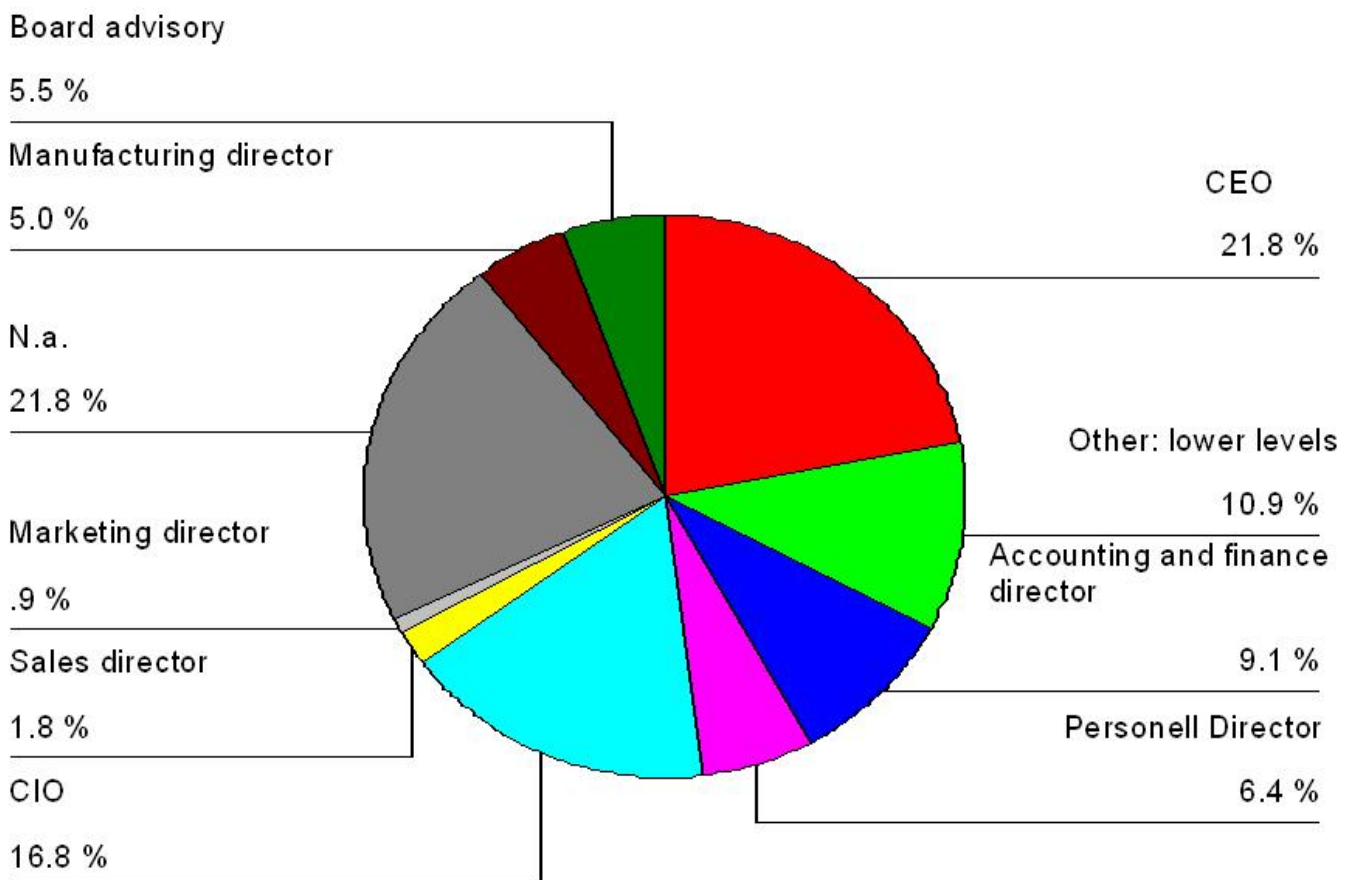

\subsection{Parameter value estimates}

The maximum likelihood (ML) method was used to estimate the parameter values. In this phase, the hypotheses posed in the conceptualisation phase are 
tested. Even though several methods can be used for this purpose, ML is the one most often used and has the advantage of being statistically efficient and at the same time specification-error sensitive because it demands only complete data and does not allow for missing values. All methods will, however, lead to similar parameter estimates on the condition that the sample is large enough and that the model is correct (Jöreskog/Sörbrom 1993). Figure 3 shows a path diagram of our model (with completely standardised parameter estimates).

\subsection{Global fit assessment}

Bollen (1989) explained that model fit relates to the degree to which a hypothesised model is consistent with the available data - the degree to which the implicit matrix of covariances (based on the hypothesised model) and the sample covariance matrix (based on the data) fit.

The aim of global fit assessment is to determine the degree to which the model as a whole is consistent with the data gathered. Through the years numerous global fit indices have been developed. To every researcher' regret, none of them is superior to the others. Different authors favour various measures. Diamantopoulos and Siguaw (2000) recommend using several measures and at the same time provide reference values for every one of them (Table 3).

Table 3. Fit indices.

\begin{tabular}{|l|c|c|c|}
\hline Fit indices & Model value & Reference value & Global fit? \\
\hline $\begin{array}{l}\chi^{2} \text { (significance } \\
\text { level } \mathrm{p})\end{array}$ & $\begin{array}{l}80.251 \\
(0.000)\end{array}$ & $\mathrm{p} \geq 0.05$ & No \\
\hline RMSEA & 0.07 & $<0.100$ & Yes \\
\hline CAIC & 259.272 & $\begin{array}{c}<\text { CAIC saturated model } \\
<\text { CAIC independence model }\end{array}$ & $\begin{array}{c}\text { Yes } \\
\text { Yes }\end{array}$ \\
\hline $\begin{array}{l}\text { Standardised } \\
\text { RMR }\end{array}$ & 0.070 & $<0.05$ & No \\
\hline GFI & 0.938 & $\geq 0.90$ & Yes \\
\hline AGFI & 0.892 & $\geq 0.90$ & On margin \\
\hline PGFI & 0.540 & $\geq 0.50$ & Yes \\
\hline CN & 167 & $\mathrm{~N}=220$ & Yes \\
\hline
\end{tabular}


Figure 3. Research model (completely standardised parameter values, ${ }^{*}$ - significant at $P>0.05$ )

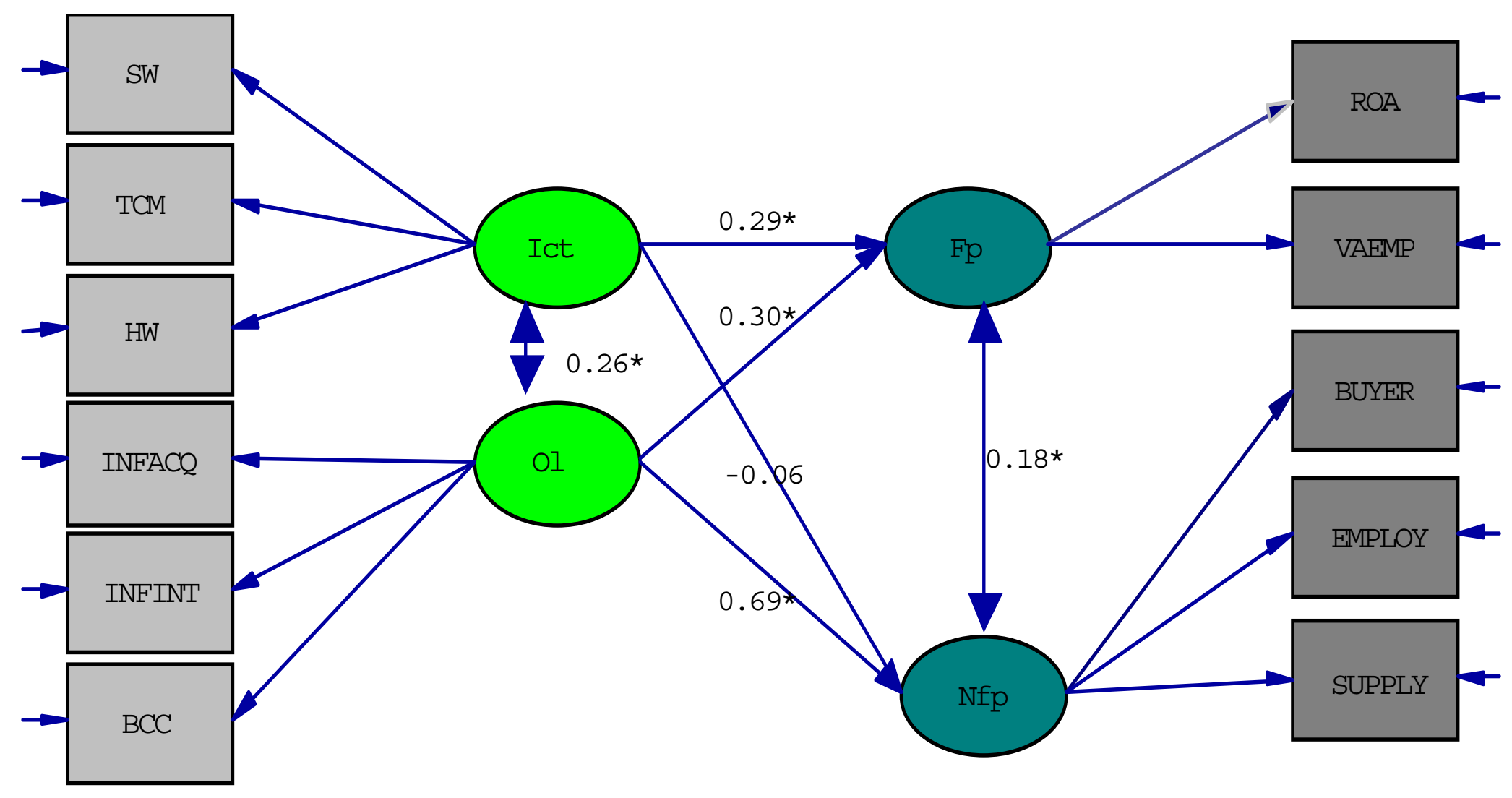


The most traditional value is $\chi^{2}$ statistics. Using this fit indicator we test the hypothesis that the implicit covariance matrix equals the sample covariance matrix. Our goal is not to reject this hypothesis. In our case this hypothesis must be rejected (at a 5\% level of significance). However, quantifying the degree of misfit is often more useful than testing the hypothesis of exact fit, which $\chi^{2}$ statistics are designed for. All other indices (except for the standardised RMR) lead to the conclusion that the model is an appropriate representation of reality. Root means square error of approximation (RMSEA) is the most widespread measure of global fit and in our case points to the acceptable fitness of the model. Consistent Akaike information criteria (CAIC) of the model needs to be compared against the CAIC for the saturated and independent model, where smaller values represent a better fit. The standardised root mean square residual (standardised RMR) is a fit index calculated from standardised residuals (differences between elements of the sample and implicit covariance matrixes). The Goodness-of-fit (GFI) index and the Adjusted goodness-of-fit (AGFI) index are absolute fit indices which directly assess how well covariances based on parameter estimates reproduce sample covariances (Gebring/Anderson 1993). All of the indices described above (except for the standardised RMR) lead to the conclusion that the model can be regarded as an appropriate approximation of reality (at the global level).

\section{Discussion of managerial implications}

When facing competing investment opportunities and projects along with limited financial, human and other resources, managers as decision-makers are always interested in some form of evaluation and justification of these projects. Our research might provide at least a small contribution by helping to justify investments in various forms of ICT and in organisational learning initiatives such as training and education.

The interpretation of results shows that the ICT productivity paradox thesis is not supported by the data we gathered. This corresponds to the results of several recent empirical studies (Dewan/Kraemer 1998; Navarette/Pick, 2002; Dimovski/Škerlavaj 2003) which prove that ICT still represent a source of competitive advantage. We can only partially agree with Carr's (2003) statement that 'IT may not help a company gain a strategic advantage, but it could easily put a company at a cost disadvantage'. In the Slovenian context, when dealing with information-communication technologies' impact on financial performance the opposite in fact holds true. When testing information-communication technologies' influence on non-financial performance, no effect was demonstrated.

Our research demonstrates a positive correlation between informationcommunication technologies and organisational learning. This means that investment in information-communication technologies, accompanied by 
systematic efforts to achieve higher-level organisational learning (deutero, strategic or generative learning), will result in better financial results. This may lead us to think of the productivity paradox as a reflection of a learning curve, which is in line with the statement that 'you can gain an edge over rivals by doing something they cannot' (Carr 2003). We believe and prove that 'something' here means higher-level organisational learning.

Interestingly, information-communication technologies did not demonstrate a statistically significant impact on non-financial performance indicators. It may be that vendors of technologies such as customer-relationship management, supply-chain management and enterprise-resource-planning systems often offer unrealistic promises when competing for information-communication technologies projects. For instance, the degree of sunk costs in investment in enterprise-resource-planning systems for Slovenia can be estimated at up to $16 \%$. One-sixth of the companies that have an enterprise-resource-planning system do not use it on a daily basis, which discredits its purpose of covering all aspects of a business model. This is where problems with the integration of legacy systems within the company occur, problems with the adaptation of information systems to business models (and not vice-versa) etc. Nevertheless, we have proven that it is worthwhile to include non-financial indicators when assessing business performance. Not surprisingly, financial and non-financial indicators do correlate. On one hand, this means that a better financial situation provides a company with more manoeuvring space to improve relationships with its stakeholders while, on the other hand, better relationships with customers, suppliers and employees lead to better financial results. Bearing in mind the debates surrounding Freeman's stakeholder theory, this is definitely an important conclusion.

Endeavours to achieve the learning organisation ideal pay off from financial as well as non-financial perspectives. Higher-level organisational learning has a strong positive impact on both return on assets and value added per employee. It even has a stronger positive influence on better relationships with customers, suppliers and the lower net fluctuation of employees. By unleashing the individual's innate aspiration to learn' (Senge 1990) and by developing the philosophy of a learning organisation, we can respond to the challenges of the modern turbulent business environment. In this context, the learning organisation needs to be perceived not just as a buzzword but as a viable solution to the successful implementation and use of informationcommunication technologies in order to solve the 'ICT productivity paradox'. This is why we believe that organisational learning can be regarded as the key to resolving the ICT productivity paradox. 


\section{Conclusion}

Our main objective was to develop a theoretical and empirical framework to simultaneously test the impact of the organisational learning process and information-communication technologies on organisational performance - in financial and non-financial terms. In the context of Slovenia, which according to many indicators is economically the most developed country within the group of the ten newcomer EU countries, some interesting results emerged. Even though Slovenian companies with more than 100 employees are relatively wellequipped with an information-communication infrastructure $(64.1 \%$ of them have enterprise-resource-planning systems system, $81.8 \%$ have intranet, $51.4 \%$ use groupware) they differ in its actual exploitation. 53\% of all companies use enterprise-resource-planning systems on a daily basis, which implies that onesixth of ERP investments can be regarded as sunk costs, knowing that enterprise-resource-planning systems aim to cover all business functions and aspects of the business model. If not used in all functional areas of a certain business on a daily basis, they can be regarded as a missed opportunity.

Companies that invest more effort in achieving higher-level organisational learning gain in both financial and non-financial terms. These results are consistent with previous empirical research (Dimovski 1994; Lam 1998; Sloan et al., 2002; Figueiredo 2003). Contrary to Chakravarthy's findings, profits achieved and value added correlate with the quality of relationships with various groups of organisational stakeholders. It is both economically wise and ethically correct to cherish good relationships with employees, suppliers and customers. Arguments for Freeman's stakeholder theory proved to be ethical as well as purely financial in their nature.

At the same time, we must be aware of some limitations of our research and directions for future research stemming from these origins. First, sample size and context always pose important limitations. We used a sample of Slovenian companies with more than one hundred employees in 2003. The authors acknowledge that smaller companies might show other patterns of behaviour which remains a challenge for future research. It would be very interesting and useful to introduce a cross-cultural dimension to the context and to crossvalidate the model in different settings (e.g. South-east Europe, EU countries, the USA, the Asian 'tigers' etc). Second, a longitudinal study could provide some additional insights into the issue of performance from higher-level organisational learning and ICT investments and use. They both might have an even stronger impact with some kind of time lag. Third, we have to be aware of problems with operationalisation of the organisational learning construct. By all means, measuring such an elusive concept poses a big challenge to the research community. Future endeavours in trying to find new measurement variables and corresponding items are needed. For instance, besides information acquisition also the quality of information (Eppler 2003) obtained might be in question. 
Nevertheless, the authors hope and believe that the model we have developed and tested presents a relatively well-balanced relationship between the complexity of the organisational learning process and organisational performance in the modern business environment on one hand, and the simplicity of its formulation in the model on the other. A significant amount of work still lies ahead. The authors hope to have demonstrated the importance of systematic efforts to achieve strategic, generative or deutero organisational learning for the strategic management of the modern company in its perpetual quest for a competitive advantage and as the key to resolving the 'ICT productivity paradox' which has already been a hot topic of discussions by academics and practitioners for decades.

\section{References}

Argyris, C./Schön, D.A. (1996): Organizational learning II: Theory, method and practice. Reading, MA: Addison-Wesley.

Andersen, T.J./Segars, A.H. (2001): The impact of IT on decision structure and firm performance: Evidence from textile and apparel industry', in: Information and Management, 39, 85-100.

Benyon-Davies, P. (2001): Information systems - An introduction to informatics in organizations. New York: Palgrave.

Bollen, K.A. (1989): Structural equations with latent variables. New York: Wiley.

Carr, N.G. (2003): IT doesn't matter, in: Harvard Business Review, 81, 5, 41.

Chakravarthy, B.S. (1986): Measuring strategic performance, in: Strategic Management Journal, 7, 437-458.

Cohen, W.M./Levinthal, D.A. (1990): Absorptive capacity: A new perspective on learning and innovation, in: Administrative Science Quarterly, 35, 1, 128-152.

Cyert, R.M./March, J.G. (1963): Behavioural theory of the firm. Englewood Cliffs: Prentice Hall.

Daft, R.L./Lengel, R.H. (1986): Organizational information requiem media richness and structural design, in: Management Science, 132, 554-571.

Daft, R.L./Weick, K.E. (1987): Toward a model of organizations as interpretation systems, in: American Management Review, 9, 284-295.

Darr, E.D./Argote, L. /Epple, D. (1995): The acquisition, transfer, and depreciation of knowledge in service organizations: Productivity in franchises, in: Management Science, 41, 11, 1750-1762.

De Geus, A.P. (1988): Planning as learning, in: Harvard Business Review, 66, 2, 70-74.

Dertouzos, M. (1997): What will be: How the new world of information technology will change our lives. San Francisco: Harper Edge.

Diamantopoulos, A. /Siguaw, J.A. (2000): Introducing LISREL. London: SAGE Publications.

DiBella, A./Nevis, E. (1998): How organizations learn - An integrated strategy for building learning capability, California: Jossey-Bass. 
Dimovski, V. (1994): Organizational learning and competitive advantage, PhD Thesis, Cleveland: Ohio State University.

Dimovski, V./Škerlavaj, M. (2003): Testing productivity paradox: The Slovenian case, in: Journal of Academy of Business and Economics, 1, 2, 53-63.

Dewan, S./Kraemer, K.L. (1998): International dimensions of the productivity paradox, in: Communications of the ACM, 41, 8, 56-62.

Dodgson, M. (1991): Technology learning, technology strategy and competitive pressures, in: British Journal of Management, 2, 3, 133-149.

Easterby-Smith, M. / Lyles, M (2003): The handbook of organizational learning and knowledge management, London: Blackwell Publishing.

Fiol, C.M./Lyles, M.A. (1985): Organizational learning, in: Academy of Management Review, 10, 803-813.

Eppler, M.J. (2003): Managing information quality, Berlin: Springer Publishing.

Freeman, E.R. (1984): Strategic management - A stakeholder approach, London: Pitman.

Figueiredo, P.N. (2003): Learning processes features: How do they influence inter-firm differences in technological capability - Accumulation paths and operational performance improvement?, in: International Journal of Technology Management, 26, 7, 655-689.

Freeman, E.R. (1994): Politics of stakeholder theory: Some future directions, in: Business ethics quarterly, 4, $409-422$.

Garvin, D. A. (1993): Building a learning organization, in: Harvard Business Review, 71, 7891.

Gerbing, D.W./Anderson, J.C. (1993): Monte Carlo evaluations of goodness-of-fit indices for structural equation models, in: Bollen, K. /Long, J.S. (eds.): Testing structural equation models, Thousand Oaks, CA: Sage.

Gill, K. S. (1996): Information society, London: Springer Publishing.

Huber, G.P. (1991): Organizational learning: The contributing process and the literatures, in: Organization Science, 2, 88-115.

Jones, G.R. (2003): Organizational theory, 4th edition. New York: Prentice Hall.

Jöreskog, K.G./Sörbrom, D. (1993): LISREL 8: Structural equation modelling with the SIMPLIS command language, London: Lawrence Erlbaum Associates Publishers.

Kaplan, R.S./Norton, D.P. (1992): Balanced scorecard - Measures that drive performance, in: Harvard Business Review, 1/2, 71-79.

Kaplan, R.S./Norton, D.P. (1993): Putting the balanced scorecard to work, in: Harvard Business Review, 9/10, 134-147.

Kaplan, R.S./Norton, D.P. (1996): Using the balanced scorecard as strategic management system, in: Harvard Business Review, 1/2, 75-85.

Kaplan, R.S./Norton, D.P. (1996a): The balanced scorecard, Boston: Harvard Business School.

King, D.W. (1980): Key papers in the economics of information, New Plains, New York: Knowledge Industry Publications. 
Kogut, B. (1988): Joint ventures: Theoretical and empirical perspectives, in: Strategic Management Journal, 9, 319-332.

Lam, S.S.K. (1998): Organizational performance and learning styles in Hong Kong, in: Journal of Social Psychology, 138, 3, 401-403.

Lane, H.W./Beamish, P.W. (1990): Cross-cultural cooperative behaviour in joint ventures in LDCs, in: Management International Review, 30, 87-102.

Lyles, M. (1988): Learning among joint venture sophisticated firms, in: Management International Review, 28, 85-98.

Martello, W.E. (1993): Scripts as practical tool for strategic action, in: Proceedings of 13th Annual International Conference, Strategic Management Society. Chicago, Illinois.

Navarette, C.J./Pick, J.B. (2002): Information technology expenditure and industry performance: The case of the Mexican banking industry, in: Journal of Global Information Technology Management, 5, 2, 7-28.

Nonaka, I./Takeuchi, H. (1996): A theory of organizational knowledge creation, in: International Journal of Technology Management, 11, 7/8, 833-846.

Pisano, G.M. /Bohmer, R.M.J. /Edmondson, A.C. (2001): Organizational differences in rates of learning: Evidence from the adoption of minimally invasive cardiac surgery, in: Management Science, 47, 6, 752-768.

Polanyi, M. (1966): The tacit dimension, London: Routledge and Kegan Paul.

Roach, S. (1987): America's technology dilemma: A profile of the information economy, in: Economics Newsletter Series, New York: Morgan Stanley.

Robey, D. /Boudreau, M. /Rose, G.M. (2000): Information technology and organizational learning: A review and assessment of research, in: Accounting, Management and Information Technologies, 10, 125-155.

Senge, P. M. (1990): The fifth discipline: The art and practice of learning organization, New York: Currency Doubleday.

Shannon, C.E. /Weaver, W. (1973): The mathematical theory of communication, Urbana, Illinois: University of Illinois Press.

Shrivastava, P. (1983): A typology of organizational learning systems, in: Journal of Management Studies, 20, 1-28.

Simonin, B.L. (1997): The importance of collaborative know-how: An empirical test of the learning organization, in: Academy of Management Journal, 40, 5, 1150-1173.

Sloan, T.R./Hyland, P.W.B./Beckett, R.C. (2002): Learning as a competitive advantage: Innovative training in the Australian aerospace industry, in: International Journal of Technology Management, 23, 4, 341-52.

Tapscott, D./Caston, A. (1993): Paradigm shift: The new promise of information technology, New York: McGraw Hill.

Tsang, E.W.K. (1997): Organizational learning and the learning organization - A dichotomy between descriptive and prescriptive research, in: Human Relations, 50, 1, 73-89.

Turban, E./McLean, E./Wetherbe, J. (2001): Information technology for management, $2^{\text {nd }}$ ed, New York: John Wiley and Sons. 
Van Wiijk, R./Van Den Bosch, F.A.J./Volberda, H.W. (2003): Knowledge and networks, in: Easterby-Smith, M. /Lyles, M. (eds.): The handbook of organizational learning and knowledge management, London: Blackwell Publishing.

Wall, B. (1998): Measuring the right stuff: Identifying and applying the right knowledge, in: Knowledge Management Review, 1, 4, 20-24. 